\title{
Political Identity: The Bargaining of Center Politic Party Spectrum on the Selection of Indonesian vice President in 2019 General
} Election (Literature Study: The Candidacy of Jokowi's vice President Candidate)

\author{
Syaifuddin, Avi Cenna Isnaini
}

Fakultas Ilmu Komunikasi Universitas Mercu Buana

\begin{abstract}
The focus of this article discusses the political identity that develops massively as one of the political instruments that had a significant influence on the vote acquisition in general elections. The main problem raised in this study is political identity which is transformed into a determinant factor which becomes a political bargaining in determining the vice presidental candidate who accompanies Joko Widodo. This paper aims to explain the process of strengthening political identity in Indonesia and finally led to the emergence of a vice-presidential candidate who accompanied Joko Widodo from non-party circles. The main theory used in this paper was the theory of identity politics taken from several literatures. The research method in this paper was a method of studying literature, using descriptive research, by a qualitative approach. The results of the literature study conducted by the author shows that the election of Kyai Ma'ruf Amin as a vice-presidential candidate to accompany Joko Widodo in the upcoming 2019 presidential election is to reduce the effectiveness and negative excesses of the sara issues inherent in Joko Widodo.
\end{abstract}

Keywords- political identity, branding, political party, general election.

\section{INTRODUCTION}

In Reformation Era, reflecting on the experience of state administration in the two previous regimes, democratization in Indonesia entered a stage of full implementation. This can be seen from the changes in various policies related to strengthening democracy in Indonesia, especially political parties and the delivery of aspirations. At this stage, political parties, which constitute a forum for aggregation and articulation of people interests, have grown massively after being severely restricted. In 1999, 2004, 2009, and 2014, the holding of democratic parties in Indonesia was followed by a number of political parties. However, there is a tendency that the journey of the multi-party system in implementing a democratic political system in Indonesia has decreased the number of national-scale political parties participating in the election. Furthermore, Islamic-based parties has smaller voters than the nationalist-based parties voters, because the large number of new political parties that emerged were unable to compete with other political parties, especially political parties that have existed since the New Order era.
To create a good democratic system, high public participation is needed. However, the level of participation of young people in politics is often a matter of debate. The younger generation is often considered as the group of people who are least concerned with political issues, who often experience a breakup with their communities, who are not interested in political processes and political issues, who have a low level of trust in politicians and are cynical about various political institutions and government (Haste \& Hogan, 2006). This view is often justified by data showing that there are relatively few young people who join political parties, and they tend to vote to be abstentions in elections (EACEA, 2012). In fact, the role of the young generation in political events is very important to the growth of a good democratic system.

Political participation according to Herbert McCloky is the voluntary activities of the citizens through which they take part in the process of electing the authorities, and directly or indirectly in the process of forming public policy. These activities include political actions such as voting in elections, attending campaigns, lobbying with politicians or the government (Purboningsih, 
2015: 108). Verba et al. (1995: 38) states that: "By political participation we refer simply to activity that has the intent or effect of influencing government action - either directly by affecting the making or implementation of public policy or indirectly by influencing the selection of people who make those policies." From this explanation, it can be interpreted that political participation includes activities to influence government action, either directly or indirectly.

As said by Ade Hikmatul above, the vote acquisition of political parties based on religious ideology (Islam) which is unable to top the national vote which further confirms the position of Islamic parties in Indonesia, where the majority of the population is Muslim, it will be difficult to bargain politics to be able to offer presidential or vice-presidential candidates themselves. However, this has slowly changed since 2012 during the election of the Governor and Deputy Governor of DKI Jakarta Province. Where the issue of primordialism especially relating to religion is used in such a massive way. Although finally the religious issue at the 2012 DKI Jakarta Pilgub was unable to effectively seize power in DKI Jakarta, this issue continues to roll like the concept of a snowball. The Islamic political movement that was once again echoed by the 2017 DKI Jakarta Pilgub has entered a peak phase which was finally able to defeat the incumbent who was attacked by religious issues and even imprisoned the incumbent.

Joko Widodo who was incumbent in the presidential election in 2019 who was so closely associated with Basuki Tjahaya Purnama (Ahok), could not help being dragged into the vortex of primordialism issues, especially religious sentiments. Jokowi since his reign has been so much attacked by various negative primordialism issues, especially those relating to religion is the most vulnerable issue for Jokowi in the upcoming presidential election battle in 2019. Therefore, religious issues or sentiments, especially Muslim bases, must be facilitated order that Ahok's defeat in the Jakarta governor election will not be experienced by Jokowi in 2019.

By this phenomenon, there are at least three interesting things to study further. First, identity politics (which in this case is religious identity) is increasingly strengthened Indonesian politic. The attitude of primodialism which the fact, is still common for the Indonesian people in several studies, has a very significant impact in the post-conflict local election. Various kinds of primordialism issues are used by candidates participating in post-conflict local elections to get support from certain groups without thinking about the negative impact of the use of primordialism issues. A study conducted by the Indonesian Survey Circle in 2008 showed that areas that were dominated by certain ethnic or ethnic groups, the issue of primordialism tended to be more massive and effective, such as in West Kalimantan, South Sulawesi and Bangka Belitung. Although these three regions are dominated by two or three particular ethnic groups, in West Kalimantan the issue of primordialism use is more effective and very thick. This is different with South Sulawesi and Bangka Belitung, the use of the issue of primordialism is more an influence factor than a determinant factor.

Second, Islamic identity which increasingly strengthened politically, according to the author's assumption, will provide its own benefits for parties based on religious ideology. It is possible that there will be one or two religious-based political parties that will penetrate the acquisition of the top 3 votes in the upcoming 2019 elections. Third, the strengthening of the position of Islam in Indonesian politic inevitably must be accommodated by actors who fight in the upcoming 2019 presidential election, especially for Jokowi who incidentally is negatively affected by greater negative than Prabowo. This is to ensure that the majority of Muslim voters can be "represented". On the other hand, this also makes the Islamic parties which in the 2019 elections occupy the middle board in the general election, are able to offer vice presidential votes for both camps (Jokowi and Prabowo).

This research will focus on examining further how the identity politics, especially those related to religion which strengthens in Indonesian politic, which in turn can become a significant political instrument and indicator in the race for votes in general elections. In addition, the author will also discuss the process of political negotiations which in turn were able to encourage representatives from non-party religious circles (Nahdlatul Utama) to become vice incumbents.

This study aims to provide an explanation of the process of identity politics in Indonesia which has been increasingly strengthened to the present which in the end political identity is able to become a bargaining tool in national politics. In addition, this research also tries to explain the process of political negotiations that ultimately led to non-party circles (in this case, Nahdlatul Ulama) as Jokowi's running mate.

\section{Political Communication}

\section{LITERATURE REVIEW}

Political communication is a conversation to influence in the life of a country. Political communication can also be the art of designing what is possible (possible art) and can even be the art of designing what is impossible (impossible art) (Arifin, 2011: 1). Littlejohn further in the theory of political communication explains the purpose in which elected leaders, the media, and citizens use messages 
to build meaning about political practice. When people use power to support the public interest, their messages and interactions are strategic ways to influence public policy (Rahman, 2018: 1168).

From some of the above notions, political communication is a communication process that has implications or consequences for political activity. This factor also distinguishes from other communication disciplines such as educational communication, business communication, intercultural communication, and others. The difference lies in the contents of the 'message'. This means that political communication has a message that is politically charged, while educational communication has messages that contain education. Thus, to distinguish between one discipline to another in the study of communication science, it lies in the nature or message. Political communication channeled people's political aspirations and interests into the political system's input. At the same time, political communication also channeled policies taken or produced from political systems.

For example, in presidential political campaigns, now routinely and actively using digital media to reach out, involve, and mobilize voters (Bimber \& Davis, 2003; Foot \& Schneider, 2006; Kreiss, 2012; Stromer-Galley, 2014). The limitations of social media enable rapid responses, fostering communities that support and push their agenda to the national stage (Kreiss, 2012; Stromer-Galley, 2014). This is similar to the process of Barack Obama political campaign which employs more than 100 staff and invests \$ 47 million in social media outreach, which includes regularly posting political updates, monitoring these messages and communicating with supporters. As can be seen from this example and more recent developments, social media has become a critical domain of communication and political competition (Hsin.2017: 77)

In democratic activities, it cannot be denied that a campaign is an important thing that must be done, to gain public trust. This is as stated by Gronbeck (1978) and Norris (1999) which explains that the campaign has various functions, including winning the battle of ideas, changing and mobilizing supporters, providing supporters of claims and information topics, and so on. This campaign is usually carried out through technology-mediated communication channels (Jensen. 2017: 22)

\section{Political Identity}

Theoretically, political identity according to Lukmantoro is politic to prioritize the interests of members of a group, because they have the same identity or characteristics, whether based on race, ethnicity, gender, or religion. Political Identity is another formulation of political differences. Political Identity is a political act to channel aspirations and to influence policy, control over the distribution of values deemed valuable to the most fundamental demands, namely self-determination on the basis of crime. In the ethnic format, political identity is reflected in the beginning of the inclusion of values in regional regulations, separating the governmental areas, the desire to land special autonomy until the emergence of the separated movement. Meanwhile, in the context of religious politics, identity is reflected in a variety of efforts to include religious values in the policy making process, including the promotion of sharia regulations, and efforts to make a city synonymous with certain religions (Nasrudin \& Nurdin, 2018: 36).

In addition, Cressida Heyes defines political identity as a sign of political activity (Cressida Heyes, 2007). In a broader sense, political identity is concerned with liberation from marginalized situations that specifically include the constituency (membership) of groups in a broader context. If examined closely political Identity is actually another name for biopolitics that speaks of a group identified by biological characteristics or biological goals from a point of view. Examples are racial politics and gender politics. (Hellner, 1994: 4). According to Agnes Heller, political identity is a political movement that focuses its attention on differences as a major political category. Political identity arises from individual awareness to elaborate particular identity, in the form of relations in ethnic and religious primordial identity (Nasrudin \& Nurdin, 2018: 37).

Agnes Heller defines identity politics as a concept and political movement that focuses her attention on differences as a major political category (Abdilah S, 2002: 16). In every community, even though they have ideology and have a common goal, there is no denying that there are various kinds of individuals who have their own personalities and identities. Thus, in general, the general theory of political identity and various research findings show that there are two main factors that make ethnicity and religion interesting and appear (salient) to be used and influence in the political process. First, when ethnicity and religion are at stake, there is a kind of need to maintain or defend the identity of a group. Second, when the political process takes place competitively, the political process causes identity groups to face each other and no one is dominant, so it is not very clear who will be the winner since the last couple years. Elections, including local elections, are political processes in which various factors such as identity are at stake. From now on, how the actors involved in managing issues such as ethnicity and religion, are at stake (Nasrudin \& Nurdin, 2018: 37).

\section{Concept of Political Participation}


Participation is an important part of democracy, in which Huntington \& Nelson (1976: 3) suggest that political participation is interpreted as a private activity of citizens carried out to influence government decisions. Then, Dahrendorf (2003) states that everyone who lives in a democratic country has the right to express their views and attitudes towards everything that happens in the public sphere or matters related to their interests so that the government knows about it and the government responds later.

Democracy itself comes from the words demos and kratos. This means that the pattern of government that comes from the people, it can also be the government (President) who is elected by the people's representatives. Meaning, the highest power is in the hands of the people. Democracy is developed to foster people's participation instead of the participation of a person or group. The role of the people (read: public) is more valued, because it plays an important role in making decisions in the public interest. You name it, such as, in determining a Regional Head, Regent, Governor, and President as head of state in a democratic system must be chosen by the people (Irawan, 2018: 91)

Participation is an important part of democracy, in which Huntington \& Nelson (1976: 3) suggest that political participation is interpreted as a private activity of citizens carried out to influence government decisions. Then Dahrendorf (2003) states that everyone who lives in a democratic country has the right to express their views and attitudes towards everything that happens in the public sphere or matters related to their interests so that the government knows about it and the government responds later.

The forms and frequency of political participation can be used as a measure to assess political system stability and citizen satisfaction or dissatisfaction. Below are the forms of political participation: 1) Conventional through voting, political discussion, campaign activities, forming and joining interest groups, individual communication with political and administrative officials, 2) Non-conventional through petition submission, demonstrating , Confrontation, Strike, Acts of political violence against property (destruction, bombing, arson), Acts of political violence against humans (kidnapping, killing), and guerrilla warfare and revolution. Thus, this study focuses on the political participation of the community to vote in the implementation of the East Java Legislative elections.

\section{General Election Concept}

According to Sukarna (1981: 83), he states that the General Election is a tool or a way to get people's representatives who will fight for the people interests and are responsible for its success. According to Aurel Croissant and friends (2003: 2), general election is a necessary condition for democracy. Furthermore, Bintan R. Saragih (1988: 167) argues that election is a sign of people will in a democracy, with the general election of a country calling itself a democracy in the true sense.

Christian Wulff's opinion is not relevant to the increasing number of community participation in democratic activities. Then, Dewey (1927) and Näsström (2003) state that democracy is based on community and for community. For a number of ethical and practical reasons, democracy is considered appropriate to involve the public in determining together to determine and change the situation. Then everyone has a say in the governance and development process (Scholte, 2014: 3). Then, Mazzuca and Munck (2014) state that democracy offers solutions for problems related to the state (Wang and Yiqing, 2018: 1).

According to Law Number 8 year 2011 concerning "General Election Organizer", Article 1 paragraph I confirms that the Election. General, hereinafter referred to as Election, is a means of implementing people's sovereignty which is held directly, publicly, freely, confidentially, honestly, and fairly in the Unitary State of the Republic of Indonesia based on Pancasila and the 1945 Constitution of the Republic of Indonesia.

In order to hold General Elections for Legislative Members, Regency / City KPU was formed as regulated in Law No. 8 of 2011 explained that the Provincial Election Commission and the Regency / City General Election Commission, hereinafter referred to as Provincial KPU and Regency / City KPU is the organizer of Elections in Province and Regency / City.

To better understand the concept of elections, we must understand the objectives, principles, and electoral systems. 1) The purpose of the general election is to elect representatives of the people and regional representatives and to form a democratic, strong government and obtain popular support in order to realize national goals. 2) The principle of general election. based on Law number 8 of 2011 Chapter II article 2: General Election is carried out effectively and efficiently based on the principle of direct, public, free, confidential, honest and fair. 3) Then, the general systems are the general election system used first, District system: this system is based on the location of the electoral district which not differentiate the population, but the place that has been determined. Second, proportional system, which is a system based on the number of residents who will become voters, for example every 40,000 voters get one representative (balanced vote) while those chosen are groups of people who are nominated by election 
contestants, namely political parties known through image markings so that representatives and less familiar voters.

\section{METHODOLOGY}

This type of research is descriptive research with a qualitative approach. According to Bodgan and Taylor, this type of research will produce descriptive data in the form of written or oral words from people and observable behavior. Thus, the research report will be in the form of data excerpts to illustrate the presentation of the report. The data comes from interview scripts, field notes, photos, videotapes, personal documents, notes or memos, and other official documents. In writing the report, the researcher analyzed very rich data and as far as possible in its original form (Jamil \& Irawan, 2018: 154).

The qualitative method also presents directly the nature of the relationship between researchers and respondents. This method is also more sensitive and more adaptable to the many sharpening of the joint influence on the patterns of values encountered. From Moleong's explanation, it can be concluded that the qualitative method is a flexible method used for social science scientific studies, because the direction of research can change according to the data obtained in the field. This is very relevant to be used in this research, remembering the object or phenomenon raised is a complex matter and requires a lot of data and information to produce a descriptive explanation and detailed analysis.

The validation technique or the validity of the data used in this study is the triangulation method. Triangulation is a data validity checking technique that utilizes something else in comparing results against research objects. Then, to establish the validity of the data, the researchers conducted a triangulation technique. Trianggulation is a data checking technique that utilizes something other than research data for checking or comparison purposes. Denzin distinguishes four types of triangulation as an examination technique that utilizes the use of sources, methods, investigators and theories (Irawan, 2018: 118).

To ensure that the research data is valid, a data validity checking process is carried out. Thus, Miles and Huberman explained that the technique of checking data validity includes three concurrent activities: data reduction, data presentation, and drawing conclusions (verification). Then, to determine the validity of the data, the researchers conducted a source triangulation technique (Yuliawati \& Irawan, 2016: 29). According to Moleong in (Kusuma, 2018: 53), he explains that in this technique the researcher compares and checks back the degree of confidence of information obtained by: (1) comparing observational data with interview data (2) comparing the consistency of the respondent's answers, namely by comparing what the resource person said in public for example, with what was said privately (3) comparing one's perspective with others in his work team.

\section{DISCUSSION}

\section{Strengthening Political Identity in Indonesia}

Seeing the phenomena, there is strengthening and thickening of identity, which will eventually lead to the politicization of identity. This politicization of identity occurs, because identity is made as a tool to gain power for political elites. Political Identity initially departed from the equality of good fortune, history, territoriality, religion, etc., which has been used as an instrument to gain public sympathy. From this explanation, it can be seen that political identity undergoes a transformation of the meaning of identity, because the identity process is made for the benefit of the people who make it instead of the sake of making the form of identity itself. All elements of the group can be a force to gain legitimacy and hegemony in society. Element group is no longer something that is not important and left behind; however, it becomes a powerful force in elections, especially local elections.

The use of primordialism issues in the political sphere in Indonesia, especially related to the post-conflict local election, has so far strengthened, because the primordial issue is one of the political instruments that is quite influential in gaining support from the community, especially the people in the regions by the minimal levels of formal education and political education. As in the North Konawe Regency which held a post-conflict local election in 2015, incumbent can be defeated by a pair of challengers, one of which is due to the use of the issue of primordialism (native son of the region). Another example is the head of a region in Papua Province, both from the regency, city, and provincial level, always filled by individuals who are Christians.

The attitude of primodialism which in fact is still very common for Indonesian people in several studies has a very significant impact in the post-conflict local election. Various kinds of use of primordialism issues are used by candidates participating in post-conflict local elections to get support from certain groups without thinking about the negative impact of the use of primordialism issues. A study conducted by the Indonesian Survey Circle in 2008 showed that areas that were dominated by certain ethnic or ethnic groups, the use of the issue of primordialism tended to be more massive and effective, such as in West Kalimantan, South Sulawesi and Bangka Belitung. Although these three regions are dominated by two or three particular ethnic groups, in West Kalimantan the use of the issue of 
primordialism is more effective and very thick. This is different with South Sulawesi and Bangka Belitung, the use of the issue of primordialism is more an influence factor than a determinant factor.

The main factor why candidates use identity issues in attracting sympathy is the sociological factors of voter behavior that tend to choose candidates based on the same ethnicity. From the above statement, it can be said that political identity was carried out because of a mass search conducted by political elites. They often map voters based on voter political behavior. This is explained in Daniel N. Posner's theory. This theory explains that there are two trends in the political elite using identity issues. First, candidate usually uses various approaches to ethnicity before the electoral arena. The target is the ethnic group concerned and those who are close to the ethnic group. Second, the candidate plays an ethnic card (playing ethnic card) to secure the limits of excellence in an arena of competition both during the election and after the election.

However, the use of the issue of primordialism does not only occur in Indonesia regions which relatively have low levels of education and income and certain ethnic dominance. In fact, in large urban areas and even in Jakarta, the use of the issue of primordialism is often used by post-conflict local election participants. This seems to confirm that the regional autonomy provides the greatest possible opportunity to foster local primordial sentiment. However, the use of the issue of primordialism in large urban areas, nowadays, tends to be increasingly ineffective. In the writer's assumption, this occurs due to the better level of education, income, and political awareness in completing democracy. This can be seen from the election of local regional head figures whose positions are so strong in urban areas, such as, Ridwan Kamil in Bandung and Tri Risma Harini in Surabaya, even Joko Widodo who was paired with Chinese ethnic and was able to become the winner of 2012 DKI Jakarta elections.

\section{Political Identity-Determinant Factor}

The assumptions above are immediately unjustifiable if we look at the reality of the DKI Jakarta post-conflict local election in 2017. The primordialism movement with ethnic and religious issues emerged massively and quickly spread into national issues. On one hand, this is indeed reasonable, because Jakarta, which is the center of government and economy, will certainly be a national spotlight. In addition, the DKI Jakarta post-conflict local election is also a measure of political power ahead of the 2019 presidential election. Thus, it is not surprising that the 2017 Jakarta post-conflict local election is very "hot". On the other hand, the high political tension during the holding of the 2017 Jakarta post-conflict local election due to the use of ethnic and religion issue will have a very negative impact on the integration of the Indonesian people. It would not only be experiece in DKI Jakarta, the disintegration has spread to the regions due to the use of these two primordialime elements.

The weakness of incumbent primordialism, which in this case expressly refers to Ahok, in the early days of the selection of prospective regional heads actually did not have a major effect on the popularity and electability of the incumbent, because the fact that the majority of DKI Jakarta people who are educated and have a high income level look more at the incumbent's performance which is considered to bring a lot of progress while leading Jakarta. Moreover, a variety of mass media coverage often highlights the physical development of Capital City of Jakarta which is very massive during the Ahok government mass; making branding "real work" incumbent by itself can eliminate the issue and sentiment of primordialism in the middle of rational DKI Jakarta society. The primordialism issue, which was initially blunted to erode the incumbent's electability in the 2017 Jakarta post-conflict local election, immediately became so sharp and effective when Ahok made a blunder in his speech in the Thousand Islands. In the speech, Ahok was considered to have insulted and defamed Islam and Islamic scholars. This, then, becomes an effective weapon for potential challenger pairs and groups that are counter to Ahok's leadership to be able to rival the incumbent pair in the 2017 Jakarta post-conflict local election.

The impact of the emergence of the blasphemy issue by Ahok in his speech in the Thousand Islands on September 2016 has made Ahok's electability slowly eroded. On March 2016, the incumbent electability which has ensured itself to advance again as a post-conflict local election participant, based on the LSI survey results, is in the range of almost $60 \%$. However, this electability is slowly decreasing when the challenger pairs that are carried by other parties have begun to cone. When the names Agus-Sylvi and Anis-Sandi emerged and were legally promoted by political parties as incumbent challengers, the incumbents' electability decreased slightly even still outperformed their challenger pairs. On July 2016, incumbent electability was in the range of $49.1 \%$. This number tends to stagnate until in October the issue of blasphemy by Ahok arises. The incumbent's electability on October dropped sharply to $31.4 \%$ and on November to $24.6 \%$. The incumbent's electability again declined sharply to $10.6 \%$ when Ahok was named a suspect on November 16,2016

DKI Jakarta post-conflict local election has made the strengthening of political identity which is not only at the 
local scale, but also it has penetrated to the national level. The Islamic Defenders Action Movement volumes one to six have made public opinion and directly formed the basis of support from Muslims to elect Muslim leaders (non incumbents). This is certainly very beneficial incumbent challenger pair. On the other hand, ethnic Chinese and Christians, also do the same thing, namely providing support to incumbents who incidentally are considered to represent them.

\section{Ahok, Religion Identity, and Jokowi}

2017 DKI Jakarta Provincial Election Contest inevitably, as explained above, has a significant influence on the map of national politics. The issue of religion that eroded the electability of Ahok as incumbent, correlated directly with Jokowi's electability as the 2019 Presidential Candidate. , the discussion on religious sentiment addressed to Ahok also indirectly gave Jokowi a negative excess. Secondly, the parties supporting Ahok in the 2017 Jakarta gubernatorial election which is also in fact the party supporting Jokowi, have formed framing for some people who are political supporters supporting religion insults.

\section{Political Negotiations of Islamic Organization}

Jokowi as incumbent by seeing the actual political reality inevitably have to make a place for the aggregation of the Muslim voice. This needs at least to reduce or minimize the negative excesses of religious sentiments that have built up on Jokowi, because to eliminate them is almost impossible and requires a relatively long time. The central parties spectrum (Islamic parties) have a very big chance to become a place for the aggregation of Islamic votes that Jokowi needs in the upcoming 2019 presidential election contest. This was fully realized not only by Jokowi, but also by Islamic parties who are currently entering the Jokowi coalition.

In the current Jokowi coalition, there are at least 2 Islamic symbol parties, namely PPP and PKB. These two parties are both NU-based Islamic mass parties. Realizing the importance of their current position, the PPP and PKB became parties that from the beginning of the Jokowi's nomination were very loudly voicing their cadres to become Jokowi's companions in the 2019 presidential election. If viewed from the acquisition of seats in the 2019 elections, PPP and PKB should be a party that would be very difficult to thrust his cadres into vice presidential candidates. Golkar, which in fact was the runner-up party for the 2014 elections, was even more marginalized in the Jokowi vice presidential stock exchange. Here, the first stage of negotiations takes place. Golkar, which is in fact a big party, is considered unable to shift the important position of the voice of Muslims at the 2019 presidential election. Other nationalist parties tend to only become followers, because the percentage of votes is actually at the bottom level. Here, PPP and PKB have an important role as party symbols or representations which are considered to represent the majority Muslim community (based on NU). The problem then is that both parties understand their strategic position, and both tend to "insist" on offering their cadres as Jokowi's companions.

The second stage of negotiations began. After the nationalist parties, including Golkar, which in fact had already "legowo" to release the position of vice presidential candidate, because it was the interests in accommodating the voice of Islam that was considered only able to be facilitated by PPP and PKB, negotiations to appoint PPP cadres or PKB cadres who would assist Jokowi. During this negotiation phase, both parties tended to provide a "threat" to leave the coalition if their cadres were not appointed as Jokowi's vice president candidate. Responding to this, Jokowi and the ranks of the supporting parties finally took the middle path by assisting NU to become vice president, because they were considered to be representatives of PPP and PKB.

In the third stage of the negotiations or the final stage, the names of Mahfud MD and Kiai Ma'ruf Amin emerged as NU's representatives who were considered to represent PPP and PKB. However, in the end, Kyai Ma'ruf was chosen as Jokowi's vice president candidate by a number of considerations. First, Kyai Ma'ruf is considered more to represent NU. Secondly, Kyai Ma'ruf is an NU official who is certain to have a strong spirit to build the loyalty of NU cadres to remote areas. Third, Kyai Ma'ruf is almost impossible to come back as incumbent candidate in the 2024 presidential election. Thus, the map of the presidential election in 2024 is still wide open for Jokowi's coalition parties to return to political bargaining.

\section{CONCLUSION}

The strengthening of political identity, nowadays, in Indonesia has made identity a determinant factor rather than merely an indicator or influence factor in the map of national politics. The defeat of several incumbents in various provinces in Indonesia including Ahok in DKI Jakarta proved the effectiveness of the political identity issue in the political sphere. This makes the parties that have Islamic identity or ideology increasingly strengthen their political bargaining. In the 2019 Presidential Election, Jokowi who incidentally is still predicted will win the presidential election, must take preventive measures and overcome the negative excesses of religious issues that attack him, namely by embracing Islamic parties and mass organizations as much as possible. This ultimately led to the appointment of Kyai Ma'ruf Amin as Jokowi's vice 
president candidate with a number of political considerations that were considered to be a win-win solution for the Jokowi coalition.

\section{REFERENCES}

[1] Cressida Heyes. 2007. Identity Politic. Amerika Serikat: Stanford Encyclopedia of Philosophy.

[2] Dahrendorf R (2003). The Challenge for Democracy. Journal of Democracy. 14 (4). EACEA (Education, Audiovisual and Culture Executive Agency) (2012). Political participation and EU citizenship: Perceptions and behaviors of young people. Evidence from Eurobarometer surveys. European Commission.

[3] Habodin, Muhtar. Menguatnya Politik Identitas di Ranah Lokal. Jurnal Pemerintahan Volume 3 Nomor 1 Februari 2012

[4] Hikmatul Fauziah, Ade. Sikap Politik PPP Dalam Suksesi Kepemimpnan Negara pada Pemilu 2014. Jurnal Sosial dan Budaya Syar'i. Vol. II. No.1. Juni 2015

[5] Hsin-Chen Lin. (2017). How Political Candidates' Use Of Facebook Relates To The Election Outcomes. International Journal of Market Research Vol. 59 Issue 1 pp. 77 - 96.

[6] Huntington, S. P. \& Nelson, J. M. (1976) No Easy Choice: Political Participation in Developing Countries. Cambridge, Mass.: Harvard University Press

[7] Irawan, Enjang Pera. The Dynamic of the Role of Volunteer as a Political Communicator: A Descriptive Study on Volunteer's Agus-Sylvi at the Election of the Jakarta Governor 2017. Asian Journal of Humanities and Social Studies (ISSN: 2321 - 2799) Volume 06 - Issue 03, June 2018

[8] Irawan, Pera Enjang. CSR Based MSME Empowerment through Product Marketing Competency Enhancement by Digital Marketing.International. Journal of Science and Research, ISSN (2319-7064) Vol-7, Issue 8. 2018.

[9] J. Moleong, Lexy. Metodologi Penelitian Kualitatif. Bandung: PT. Remaja Rosda Karya. 2011

[10] Jamil Achmad \& Irawan, Pera Enjang. The Analysis of Lebak Smart City Application Based on Mobile in Improving Lebak Regency Government Service. International Journal of Sciences: Basic and Applied Research (IJSBAR) (2018) Volume 39, No 2, pp 149-164

[11] Jensen J Michael. (2017). Social Media and Political Campaigning: Changing Terms of Engagement?. The International Journal of Press/Politics, Vol. 22(1) 23-42.

[12] Kreiss, D. (2012). Taking our country back: The crafting of net- worked politics from Howard Dean to Barack Obama. Oxford, UK: Oxford University Press.

[13] Kusuma, Kurniastuti. Activities of the Cyber Public Relations of O Chanel TV in Promoting their Company on the Instagram Social Media. American Journal of Humanities and Social Sciences Research (AJHSSR. Volume-02, Issue-09, pp-50-56 2018

[14] Lingkar Survei Indonesia, Faktor Etnis Dalam Pilkada. Kajian Bulanan Edisi 09. Januari 2008

[15] Nasrudin, Juhana and Nurdin, Ahmad Ali . Politik Identitas Dan Representasi Politik (Studi Kasus pada Pilkada DKI
Periode 2018-2022). Hanifiya: Jurnal Studi Agama-Agama ISSN 2089-8835 Volume 1 Nomor 1 Tahun 2018

[16] Rahman A H.I. Political Messages Processing of Presidential Candidate through Heuristic and Systematic Model in the 2014 Presidential Election in Indonesia. International Journal of Science and Research (IJSR). Volume 7 Issue 7, July 2018

[17] Wang Erik H. dan Yiqing Xu. (2018). Awakening Leviathan: The Effect Of Democracy On State Capacity. Research \& Politics, vol. 5, 2 pp. 1-7.

[18] Yuliawati \& Irawan, Pera Enjang. Peran Cyber Public Relations Humas Polri Dalam Memberikan Pelayanan Informasi Publik Secara Online. Vol 1, No 1 (2016): JURNAL POLITIKOM INDONESIANA. 